\title{
«PER SERVEY DE LA CORONA D’ARAGÓ». IDENTIDAD URBANA Y DISCURSO POLÍTICO EN LA FRONTERA MERIDIONAL DEL REINO DE VALENCIA: ORIHUELA EN LA CORONA DE ARAGÓN, SS. XIII-XV*
}

\author{
JUAN ANTONIO BARRIO BARRIO
}

Universidad de Alicante

RESUMEN: Este artículo analiza los mecanismos de construcción de un discurso político y una identidad urbana en el observatorio de la ciudad de Oribuela a partir de su incorporación a la Corona de Aragón en 1296 y la evolución de dichos fenómenos durante los siglos XIV y XV. Planteamos un método de estudio que se puede aplicar a villas o ciudades de tamaño medio y que evolucionaron en escenarios históricos o territoriales singulares. En el caso de la ciudad de Oribuela, su evolución histórica entre 1243 y 1304, con el cambio de soberanía política en tres momentos, la transformación de la villa primero en capital de una demarcación territorial y después la recepción del título de ciudad en 1437, y su ubicación fronteriza y geoestratégica clave para los intereses de la Corona de Aragón y del reino de Valencia propiciaron y estimularon en sus grupos dirigentes el desarrollo de un discurso politico y una identidad que remarcaban su posición fronteriza y la necesidad de sus servicios a la monarquía, la capitalidad sobre el territorio y la aspiración secular a una diócesis propia, todo ello en un escenario que fue prioritario y clave en las tensiones bélicas que se produjeron entre las dos grandes potencias peninsulares entre la segunda mitad del siglo XIII y el siglo XV, con hechos tan decisivos como la guerra de los dos Pedros y la ubicación de una parte importante del esfuerzo militar de las dos Coronas implicadas en las tierras del sur de Valencia.

Palabras clave: $\quad$ Edad Media. Corona de Aragón. Orihuela. Discurso. Identidad. Memoria.

Juan Antonio Barrio Barrio es profesor titular de Historia Medieval de la Universidad de Alicante. Dirección para correspondencia: Departamento de Historia Medieval, Historia Moderna y Ciencias y Técnicas Historiográficas, Facultad de Filosofía y Letras, Universidad de Alicante, carretera de San Vicente del Raspeig s/n,03690-San Vicente del Raspeig, Alicante.Correo electrónico:ja.barrio@ua.es.

* El presente artículo se ha realizado en el marco del proyecto de investigación «Fundamentos de identidad política: la construcción de identidades políticas urbanas en la península ibérica en el tránsito a la modernidad», HAR2009-08946. 
«TO SERVE THE CROWN OF ARAGÓN». URBAN IDENTITY AND POLITICAL DISCOURSE IN THE KINGDOM OF VALENCIA'S SOUTHERN FRONTIER: ORIHUELA IN THE CROWN OF ARAGON, $13^{\mathrm{TH}}-15^{\mathrm{TH}}$ CENTURIES.

ABSTRACT: From the Oribuela Observation Group, this paper analyses the mechanisms behind the political discourse and urban identity that developed in the city of Oribuela following its incorporation into the Crown of Aragon in 1296, as well as the evolution of these two phenomena during the $14^{\text {th }}$ and $15^{\text {th }}$ centuries. We used a study method that can be applied to medium-sized towns and cities that evolved in unique bistoric or territorial settings. The political development of Oribuela between 1243 and 1304, which included three changes in political leadership, together with the fact that it was named capital of a territorial demarcation, granted city status in 1437 and converted into a key geostrategic and frontier location for both the Crown of Aragon and the Kingdom of Valencia, led local leaders to develop a political discourse and identity that emphasised the city's frontier position and the monarchy's need for its services, its position as a territorial capital and the secular aspirations for a diocese of its own. All of this occurred in a pivotal area that played a key part in the bellicose tension that existed between the Iberian Peninsula's two main powers in the period spanning from the mid-13 $3^{\text {th }}$ to the $15^{\text {th }}$ century, and bore witness to such decisive events as the War of the Two Peters and the concentration of significant military efforts by both Crowns in their battle to win over the lands of southern Valencia.

KEY WORDS: Middle Ages. Crown of Aragon. Orihuela. Discourse. Identity. Memory.

\section{FEREN HOMENATGE DE BOCA ET DE MANS AL DAMUNT DIT SENYOR REY EN JACME. LA ARTICULACIÓN INICIAL DE LA IDENTIDAD URBANA Y EL DISCURSO POLÍTICO}

El proceso histórico ${ }^{1}$ de construcción del discurso político y la elaboración de modelos de identidad política urbana en la Edad Media es un fenómeno cada vez mejor conocido ${ }^{2}$. En las ciudades europeas se desarrollaron procesos de creación de identidades propias y específicas desde los siglos centrales del medioevo y articuladas en torno a un discurso redactado y expresado desde y para una sociedad ${ }^{3}$.

${ }^{1}$ Las abreviaturas utilizadas son: AHN (Archivo Histórico Nacional); AHO (Archivo Histórico de Orihuela); AMO (Archivo Municipal de Orihuela); ARV (Archivo del Reino de Valencia); ACA (Archivo de la Corona de Aragón).

${ }^{2}$ Una amplia bibliografía se puede consultar en NiETO SORIA, José Manuel, Orígenes de la monarquía hispánica: propaganda y legitimación (ca. 1400-1520), Madrid, Dykinson, 1999, págs. 537-589.

${ }^{3}$ Guglielmi, Nilda, «El discurso político en la ciudad medieval italiana (Siglos XIV-XV)», en Guiglielmi, Nilda y RucQuoI, Adeline (coords.), El discurso político en la Edad Media. Le discours politique au Moyen Age, Buenos Aires, CONICET-CNRS, 1995, pág. 54. 
El discurso actuó como una poderosa herramienta al servicio de los que gobiernan, que podían utilizar la oralidad ${ }^{4}$, la escritura y la imagen ${ }^{5}$ para articular un mensaje en beneficio propio, sobre todo para justificar y legitimar el origen y los fundamentos del poder ejercido ${ }^{6}$. En la creación del discurso, se utilizaban técnicas novedosas que se habían incorporado en fechas recientes al bagaje intelectual de la Corona de Aragón, como el ius commune, el ars dictandi y el ars notariae, que fueron ejecutadas por los técnicos del derecho - canonistas-, y los especialistas en la escritura - notarios-, que se pusieron al servicio de los agentes del poder en el territorio, la monarquía y el municipio. La identidad, por otra parte, actúa como un instrumento que permite integrar tanto a los que ejercen el poder como aquellos sobre los que se ejecuta la acción de gobierno, en un espacio ideológico y simbólico común reconocible por todos, a través de unos referentes discursivos comunes ${ }^{7}$. Es el espacio de la Christianitas $^{8}$, común a toda la cristiandad occidental, y el de la Corona de Aragón, afín a los súbditos de la monarquía aragonesa, en el que se encuadran los vecinos de Orihuela.

Las cuatro formas de poder que garantizan la cohesión de una comunidad, ideológica, económica, militar y política, a juicio de Michael Mann9, permiten analizar las formas de organización social de la misma, según el predominio de unas u otras ${ }^{10}$. Desde esta perspectiva, Lehtonen muestra el papel decisivo de la

${ }^{4}$ Sobre la evolución del arte de la memoria anterior a la imprenta, Frances Yates enfatiza el papel de las imágenes y la transformación que va a suponer la aparición del libro impreso, que hará innecesarias esas enormes construcciones de la memoria atestadas de imágenes y destruirá hábitos de la memoria de antigüedad milenaria. Echamos en falta en esta obra una consideración del rol desempeñado por la introducción del papel en Occidente y la decisiva aportación de la creación de los registros documentales, fenómenos desarrollados con anterioridad a la aparición de la imprenta en Europa. YATES, Frances Amelie, El arte de la memoria, Madrid, Taurus, 1974.

${ }^{5}$ Durante la Edad Media se forjaron fórmulas plurales y variadas de transmisión del mensaje ideológico. Cammarosano, Paolo, «Immagine visiva e propaganda nel Medioevo», en Cammarosano, Paolo, (ed.), I linguaggi della propaganda: studio di casi: medioevo, rivoluzione inglese, Italia liberale, fascismo, resistenza, Milán, Modadori, 1991, pág. 8.

${ }^{6}$ Son los mitos fundacionales y de legitimación que se encuentran en la base del poder monárquico ejercido en diferentes zonas de Europa, Inglaterra, Francia, Corona de Aragón, etc. Freedman, Paul, Images of the Medieval Pesant, Stanford, Stanford University Press, 1999, págs. 105-130. Este legítimo ejercicio del poder justifica el dominio sobre tierras y hombres, y las respectivas relaciones con súbditos, vasallos, siervos, etc.

7 Entendiendo la identidad como un proceso complejo nunca completado o finalizado y que se desarrolla de forma dinámica en una construcción, tanto individual como comunitaria. EVANGELISTI, Paolo, «Mercato e moneta nella costruzione francescana dell'identità politica. Il caso catalano-aragonese», Reti Medievali Rivista, VII/1 (2006).

${ }^{8}$ Para el concepto de Christianitas, vid. BARTLETT, Robert, La formación de Europa. Conquista, colonización y cambio cultural, 950-1350, Valencia-Granada, Universitat de València-Universidad Granada, 2003.

${ }^{9}$ MANN, Michael, Las fuentes del poder social. Vol. I. Una historia del poder desde los comienzos hasta 1760 d.C., Madrid, Alianza Editorial, 1991, págs. 15, 27-28, 43-56.

${ }^{10}$ En una explicación similar propuesta por Blockmans, se echa en falta la consideración del papel de la categoría militar como componente esencial de toda forma de poder perdurable. Vid. 
escritura $^{11}$, que permitió la evolución de los poderes ideológicos, económicos y políticos, y que tuvo una influencia indirecta sobre el poder militar. En este contexto ubica la reorganización del poder en Suecia, Finlandia y Estonia entre los siglos XII y XIV a partir de la conversión al cristianismo y la introducción de la escritura y el latín en estos espacios. Michael Mann también plantea que el poder ideológico permite determinar la interpretación que la comunidad hace de la realidad ${ }^{12}$. La conversión de los reinos nórdicos al cristianismo es explicada ${ }^{13}$, de esta forma, como la victoria de una nueva interpretación de la historia a través de los nuevos discursos de legitimación presentes en las crónicas dinásticas y otros documentos escritos ${ }^{14}$. Las conquistas del reino de Valencia y del reino de Murcia, y la posterior reorganización del poder en los mismos se hizo en un contexto similar, ya que fue decisiva la cristianización del territorio y la introducción del lenguaje y las formas escriturarias latinas para la inmersión de territorios que habían formado parte de Dar-el-Islam desde el siglo VIII, en los referentes ideológicos de la cristiandad occidental.

Las oligarquías urbanas utilizaron la herramienta del discurso político en su relación con la monarquía. En la Corona de Aragón, el papel de gran potencia mediterránea había obligado a la dinastía a la construcción de un discurso político propagandístico, que utilizaba las grandes crónicas $^{15}$ para expresar la perpetuación de la memoria, la conciencia del linaje, los modelos de poder y su representación a través de la utilización de las grandes celebraciones como las ceremonias de coronación o los funerales de los soberanos ${ }^{16}$ y que fue emulado

BLOCKMANS, Wim, «La manipulation du consensus. Systèmes de pouvoir a la fin du Moyen-Age», en Gensini, Sergio, (ed.), Principi e città alla fine del Medioevo, Roma, Pacini Editore, 1996, págs. 433-447.

${ }^{11}$ Sobre el papel de la escritura en la evolución del conocimiento, vid. OLSON, David R., El mundo sobre el papel. El impacto de la escritura y de la lectura en la estructura del conocimiento, Barcelona, Gedisa, 1998. Olson, David R. y TORRANCE, Nancy (comps.), Cultura escrita y oralidad, Barcelona, Gedisa, 1998. PetruCCI, Armando, Alfabetismo, escritura, sociedad, Barcelona, Gedisa, 1999.

${ }^{12}$ MANN, Las fuentes del poder social. Vol. I.

${ }^{13}$ Lehtonen, Thomas, M.S., «Préliminaires. Colonisation et culture écrite: les sources du pouvoir des élites au nord de la mer Baltique», en LEHTONEN, Thomas M.S. y MORNET, Élisabeth, Les élites nordiques et L'Europe occidentale (XIIe-XVe siècle), París, Publications de la Sorbonne, 2007, pág. 15.

${ }^{14}$ En la Edad Media la memoria se convirtió en un recurso imprescindible, tanto en la oralidad como sobre todo en las sociedades alfabetizadas que hacían un uso masivo de la escritura. Carruthers, Mary J., The Book of Memory. A Study of Memory in Medieval Culture, Cambridge, Cambridge University Press, 1993.

${ }^{15}$ Cingonali, Stefano Maria, Historiografia, propaganda i comunicació al segle XIII: Bernat Desclot $i$ les dues redaccions de la seva crònica, Barcelona, Institut d'Estudis Catalans, 2006.

${ }^{16}$ Vid. Corrao, Pietro, "Celebrazione dinastica e costruzione del consenso nella Corona d'Aragona», en Cammarosano, Paolo, (ed.), Le forma della propaganda politica nel Due e nel Trecento, Roma, École française de Rome, 1994, págs. 133-156. SaBATÉ, Flocel, Lo Senyor Rei És Mort! Actitud $i$ Cerimònies dels municipis catalans Baix-Medievals Davant la Mort del Monarca, Lleida, Universitat de Lleida, 1994. 
por las ciudades y villas con sus propias ceremonias festivas, como en Valencia con la celebración del 9 de octubre, a partir de $1338^{17}$. Otro instrumento de difusión de la ideología y la política real en la Corona de Aragón era el envío de documentos y cartas a todas las ciudades del dominio de la Corona ${ }^{18}$, ya que los textos eran leídos y expuestos en público ${ }^{19}$. Eran estos textos los que servían de referente para la elaboración de un discurso político propio a los juristas y al notariado local ${ }^{20}$, que ponían sus conocimientos técnicos al servicio de los grupos dirigentes de las ciudades de la Corona de Aragón. Los notarios de la Corte conocían el Ars dictandi y el Ars notariae, por lo que, tras la supervisión correspondiente del protonotario, eran capaces de producir documentos elaborados sobre la base de la retórica y utilizando figuras literarias, o citas de otros textos, como las sagradas escrituras, con el ánimo de no emplear fórmulas repetitivas y ofrecer cierta originalidad en el estilo y el contenido de privilegios, epístolas, provisiones, etc., promulgados por la cancillería regia ${ }^{21}$.

Las herramientas discursivas más utilizadas son la elocuencia verbal, la escritura, la representación iconográfica ${ }^{22}$ y la epigrafía ${ }^{23}$. También se articulaban actuaciones políticas y diplomáticas que podían tener una cierta repercusión pública mediante la promulgación de privilegios, ordenanzas, etc. Este dominio del discurso que se extendía al mundo de las manifestaciones artísticas como instrumento de poder $^{24}$, de la fiesta y de la ceremonia pública se organizaba

${ }^{17}$ Para el estudio del fenómeno del papel de las ceremonias cívicas en el reino de Valencia, vid. Narbona Vizcaíno, Rafael, Memorias de la Ciudad. Ceremonias, creencias y costumbres en la historia de Valencia, Valencia, Ayuntamiento de Valencia, 2003.

${ }^{18}$ BARRIO BARRIO, Juan Antonio, «Los privilegios reales. Centralización y transmisión de la política real», en BARRIO BARRIO, J.A. (ed.), Los cimientos del Estado en la Edad Media. Cancillerías, notariado y privilegios reales en la construcción del Estado en la Edad Media, Alcoy, Marfil, 2004, págs. 119-156.

${ }^{19}$ CORRAO, «Celebrazione dinastica e costruzione del consenso», pág. 145.

${ }^{20}$ Sobre la actividad de los notarios en la ciudad de Valencia, vid. CRuSElles, Jose María, Els notaris de la ciutat de València. Activitat profesional i comportament social a la primera mitad del segle XV, Barcelona, Fundació Noguera, 1986.

${ }^{21}$ BARREDA I EDO, Pere Enric, «Elements retòrics en les clàusules dels documents llatins de la cancilleria real (Segles XIV-XV)», en Actes del VII Congrés de l'associació hispànica de literatura medieval (Castelló de la Plana, 22-26 de setembre de 1997), vol. I, Castelló de la Plana, Universitat Jaume I, 1999, págs. 305-319.

${ }^{22}$ MANZI, Ofelia, «La expresión del poder en la iconografía de la ciudad», en Guiglielmi y RUCQUOI, El discurso político en la Edad Media, págs. 169-187. En esta representación iconográfica hay que incluir la sigilografía y la numismática. Una de las imágenes más comunes que representan la autoridad municipal son los sellos. SAINT-DENIS, Alain, «L'apparition d'une identité urbaine dans les villes de commune de France du Nord aux XIIe et XIIIe siècles», en BoONE, Marc y STABEL, Peter, (eds.), Shaping Urban Identity in Late Medieval Europe, Leuve-Apeldoorn, Garant, 2000, págs. 65-66, n. 3 y 4 .

${ }^{23}$ MarChIOLI, Nicoletta Giovè, «L'epigrafia comunale cittadina», en Cammarosano, Le forma della propaganda politica, págs. 263-286.

${ }^{24}$ Orlandoni, Bruno, «Le immagini del potere. Saggio iconografico», en Tranfaglia, Nicola y FIRPO, Massimo (dirs.), La Storia. I grandi problemi dal Medioevo all'Età Contemporanea, vol. 2, Il Medioevo, 2. Popoli e strutture politiche, Torino, UTET, 1993, págs. 757-801. 
con astucia para transmitir un mensaje político específico y para suscitar la adhesión a una causa determinada ${ }^{25}$. En la ciudad de Orihuela todavía hoy son visibles elementos iconográficos y artísticos que muestran con vehemencia la adhesión inquebrantable del municipio medieval a la Corona de Aragón ${ }^{26}$.

Los sistemas discursivos de los municipios del sur del reino de Valencia pueden ser estudiados a través de la iconografía y, sobre todo, la documentación escrita conservada ${ }^{27}$, ya que las actas de las reuniones de los consejos municipales, las ordenanzas promulgadas, las cartas y los memoriales remitidos a los diferentes interlocutores políticos son una herramienta de trabajo de primera línea para conocer la construcción y la evolución del mensaje político de las elites gobernantes. En primer lugar, parece claro el papel desempeñado por la nueva clase de notarios y juristas ${ }^{28}$ en la elaboración de un lenguaje jurídico y político sólido tanto en sus argumentaciones como en el estilo utilizado. Se realizaba por parte de los munícipes un esfuerzo significativo para elaborar documentos bien redactados, ordenam una bona scriptura recitant per aquella los caps, para lo que se recurría a especialistas como el Síndico de la ciudad y los juristas más sobresalientes de la localidad $^{29}$. En 1449 el lugarteniente general del reino de Valencia, en carta remitida a las autoridades de Orihuela, respondía que, tras leer una misiva que le habían remitido, se había sorprendido de vostre stil e orde en escriure ${ }^{30}$.

Vamos a centrar en el eje de nuestro análisis en el observatorio de la ciudad de Orihuela ${ }^{31}$, una urbe fronteriza del sur del reino de Valencia, de tamaño

\footnotetext{
${ }^{25}$ VERGER, Jacques, «Théorie politique et propagande politique», en CAMMAROSANO, Le forma della propaganda politica, págs. 29-44.

${ }^{26}$ Una selección de estas imágenes se pueden contemplar en MiLlán, Jesús (coord.), Fronteras e identidades en el sur valenciano, siglos XIII-XVI, Orihuela, Ayuntamiento de Orihuela, Concejalía de Cultura, 2005.

${ }^{27}$ La producción literaria ciudadana, de carácter municipal y laica es la base de la elaboración de una memoria histórica, con una fuerte impronta de memoria política. BORDONE, Renato, Uno stato d'animo. Memoria del tempo e comportamenti urbani nel mondo comunale italiano, Florencia, Firenze University Press, 2002, pág. 6. El grupo dirigente se constituye en «clase política» que se interpone entre la comunidad y las autoridades exteriores a la misma, forjando una memoria política que reconoce y registra en la documentación esta posición. GRAVA, Yves, «La mémoire, une base de l'organisation politique des communautés provençales au XIV ${ }^{e}$ siècle», Temps, mémoire, tradition au Moyen-Age, Aix-en-Provence, Université de Provence, 1983, pág. 77.

${ }^{28}$ Sobre el papel de los juristas, vid. LATORRE, Angel, Derecho: Orígenes y transformación del 'Corpus Iuris Civilis', en DuBY, Georges, (Dir.), Los ideales del Mediterráneo. Historia, filosofía y literatura en la cultura europea, Barcelona, Icaria, 1997, págs. 171-188.

${ }^{29}$ En 1448 el Consell de Orihuela, agraviado por una provisión del lugarteniente general del reino de Valencia, ordenó el envío de un mensajero que debía comparecer ante él con un memorial detallando en capítulos los motivos de su queja, debiendo estar perfectamente redactado y esbozada la argumentación. Para ello se nombraba una comisión encargada de la redacción del escrito, presidida por el Justicia criminal y los jurados, y con el asesoramiento técnico del Síndico y los juristas más destacados de la ciudad. AHO, Contestador, n. ${ }^{\circ} 28$, f. $41 \mathrm{r}$-v.

${ }^{30} \mathrm{AHO}$, Contestador, n. ${ }^{\circ} 28$, f. $51 \mathrm{v}$ (1448, mayo, 18. Elche).

${ }^{31}$ No hemos incluido en este artículo, por razones de espacio, cuestiones consideradas fundamentales en la construcción de la identidad urbana como la configuración política, social,
} 
medio y con una población en torno a los diez mil habitantes ${ }^{32}$. Cada ciudad define su propio perfil social en función de las actividades predominantes: la religiosa, propia de las ciudades episcopales o de las ciudades-santuario; la cultural, a través de centros de estudios y enseñanza; la de capitalidad política o sede regia; la militar, que se hace presente, por ejemplo, en las ciudades de frontera, etc. ${ }^{33}$. La ciudad de Orihuela responde a los dos últimos perfiles, por su capitalidad y su posición fronteriza.

En 1296 una treintena de notables de Orihuela ${ }^{34}$ prestaban solemne juramento en la iglesia parroquial de San Salvador, futura sede Catedral, ante Jaime II. La protesta pública realizada ante el rey Justo adquiría una gran trascendencia. Era un cambio radical en la historia de Orihuela. Desde 1243 y en virtud de lo acordado en el Tratado de Alcaraz, el reino de Murcia había quedado incorporado a la soberanía de la Corona castellano-leonesa. Pero fue a

económica, ritual y simbólica de los espacios de la ciudad. Para este tipo de análisis, vid. BoONE y STABEL, Shaping Urban Identity. Asimismo hemos eliminado en la redacción final un epígrafe dedicado a la identidad cívica de la comunidad. Sobre la identidad cívica y la identidad civil, vid. SolóRZANo TelecheA, Jesús Ángel, «Linaje, comunidad y poder: Desarrollo y consolidación de identidades urbanas contrapuestas en la Castilla Bajomedieval», en Familia y Sociedad en la Edad Media (Siglos XII-XV). Aragón en la Edad Media: sesiones de trabajo: Seminario de Historia Medieval, Zaragoza, Universidad de Zaragoza, 2007, págs. 71-93.

32 BARrio BARRIO, Juan Antonio, «Inmigración, movilidad y poblamiento urbano en un territorio de frontera. La Gobernación de Orihuela a fines del medievo», Revista d'Història Medieval, 10 (2000), págs. 199-231.

${ }^{33}$ RUIZ DE LA PeÑa Solar, Juan Ignacio, «Ciudades y sociedades urbanas en la España Medieval (siglos XIII-XV)», en XXIX Semana de Estudios Medievales, Pamplona, Gobierno de Navarra, 2003, pág. 22-23.

${ }^{34}$ En este documento aparece el primer listado extenso de miembros del grupo dirigente en la documentación histórica de la ciudad medieval de Orihuela. Estos listados exhaustivos de jurados y consellers van ser una característica común del discurso político de numerosos municipios de la Corona de Aragón. En los registros municipales se van a elaborar listas reiteradas y reiterativas de jurados, consellers, insaculados, etc. Así lo ha puesto de manifiesto Rafael Narbona en un reciente artículo, en el que se interroga sobre el valor que podían tener para los grupos urbanos «las extensas y minuciosas actas notariales y su interés por dejar constancia pormenorizada del nombre del miembros del Consell y de los cargos electos, aun desempeñando estos funciones de carácter subsidiario». NARBONA VizCAÍNO, Rafael, «Algunas reflexiones sobre la participación vecinal en el gobierno de las ciudades de la Corona de Aragón (ss. XII-XV)», Res publica, 17 (2007), pág. 116. Se producía la elaboración de una memoria política que recoge las acciones honorables de los miembros de la oligarquía. Sobre la memoria política, vid. BORDONE, Uno stato d'animo, pág. 5. Pero también conocemos la elaboración de listados de vecinos desterrados de la ciudad de Orihuela. Giulano Milani ha analizado los registros de proscritos en Bolonia. Vid. Milani, Giulano, "Il Governo delle liste nel Comune di Bologna. Premesse e genesi di un libro di proscrizione duecentesco», Rivista Storica Italiana, 108 (1996), págs. 149-229; y «La memoria dei rumores. I disordini bolognesi del 1274 nel ricordo delle prime generazioni: note preliminare», en DelLE DonNe, Roberto y ZoRZI, Andrea, Le Storie e la memorie. In onore di Arnold Esch, Florencia, Firenze University Press, 2002, págs. 271-293. 
partir del fin de la revuelta de los mudéjares murcianos ${ }^{35}$ cuando arranca con brío la historia cristiana de Orihuela. A partir de este momento, se inicia el poblamiento cristiano de su urbe y territorio, utilizando la fórmula del repartimiento ${ }^{36}$ y la lenta organización institucional de la localidad, a través de la vía del concejo y de la recepción de fueros castellanos.

Con este solemne e irrevocable juramento, se ponía fin de forma inopinada y súbita a un recorrido histórico dentro de la Corona de Castilla. El tratado de Almizra saltaba hecho añicos por los aires. Con el anhelado juramento prestado ante Jaime II ${ }^{37}$ moría Almizra y se ponía la simiente de Torrellas. El orden político establecido entre la Corona de Castilla y la Corona de Aragón en el siglo XIII quedaba viejo y anquilosado y se iniciaba un nuevo tiempo, vital para el equilibrio peninsular entre sus dos grandes potencias, la Corona de Castilla y la Corona de Aragón.

Las consecuencias de la Sentencia Arbitral de Torellas de 1304 trascienden con creces el ámbito de la Gobernación de Orihuela para proyectarse sobre el reino de Valencia, la Corona de Aragón e incluso sobre el resto de la península ibérica al convertirse con el paso del tiempo en la causa que permitió reabrir la lucha por la hegemonía peninsular a mediados del siglo XIV cerrada en falso en Almizra y en el propio Acuerdo de Torrellas, con la decisión de Pedro I de intervenir en el mediodía de la Corona de Aragón para reincorporar estas tierras al reino de Murcia, provocando un grave conflicto bélico, la guerra de los dos Pedros, que a la postre le costó la vida, propició la instauración de una nueva dinastía en Castilla, los Trastámara, que años después también gobernarían en la Corona de Aragón, y generó, como en Francia e Inglaterra con la Guerra de los Cien Años, la exacerbación de las identidades nacionales en los territorios del sur del reino de Valencia, más afectados por la crueldad de los efectos de la guerra sobre sus tierras y gentes ${ }^{38}$.

${ }^{35}$ TORRES Fontes Juan. La reconquista del reino de Murcia en 1266 por Jaime I de Aragón, Murcia, Academia Alfonso X el Sabio, 1967.

${ }^{36}$ Para conocer con detalle el desarrollo del proceso histórico del repartimiento de Orihuela, vid. TORres Fontes, Juan, Repartimiento de Oribuela, Murcia, Patronato Ángel García Rogel, 1988. FERrer I MALLOL, M. ${ }^{a}$ T., «Repartiments de terres a Oriola després de la conquesta de Jaume II», en Acta historica et archaeologica Medievalia, 22, vol. 2, Homenatge al Dr. Manuel Riu i Riu, Barcelona, Universitat de Barcelona, 1999-2001, págs. 509-535. BARRIO BARRIO, J.A., «Un repartimiento inédito, el repartimiento de Orihuela de 1330», en Toro Ceballos, F. y Rodríguez Molina, J. (coords.), VI Estudios de Frontera. Homenaje a Manuel González Jiménez, Jaén, Diputación Provincial de Jaén, 2006, págs. 79-92.

${ }^{37}$ Defendemos que la entrada de Jaime II en el reino de Murcia había sido pactada previamente con las autoridades locales de villas del reino como Orihuela, en la misma línea planteada por otros investigadores. Ferrer I MALlol, M. ${ }^{a}$ T. «Notes sobre la conquesta del regne de Múrcia por Jaume II (1296-1304)», en Homenatge a la memòria del Prof. Emilio Sáez. Aplec d'estudios del seus deixebles i col.laboradors, Barcelona, Universitat de Barcelona, 1989, págs. 27-44.

${ }^{38}$ Barrio Barrio, Juan Antonio y CABezUelo Pliego, José Vicente, «Las consecuencias de la sentencia arbitral de Torrellas en la articulación del reino de Valencia», en NARBONA Vízcaino 
Tras la incorporación del reino de Murcia a la Corona de Aragón en 1296, era el momento de iniciar la construcción de un discurso político nuevo. El idioma oficial anterior, el castellano, quedaba deslegitimado y se convertía en el vehículo de expresión del enemigo. Las palabras y los conceptos que todavía flotaban en el aire, Castilla, Concejo, quedaban de repente obsoletos y la nueva clase dirigente se aprestaba a sepultar en el olvido ${ }^{39}$. El propio Jaime II llegó a utilizar el castellano para dirigirse a algunos municipios del reino de Murcia, en los momentos previos a la conquista del mismo. Una carta remitida a las autoridades de la villa Guardamar en abril de 1296, está escrita en castellano ${ }^{40}$. Era el liviano y rápido tránsito entre el viejo y el nuevo orden.

El recién instaurado discurso político de base castellana quedaba de inmediato arrumbado en la memoria histórica y la nueva cúpula dirigente urbana territorial se debía aprestar en la elaboración de un nuevo discurso político, acorde con la nueva era histórica que se iniciaba y la correspondiente memoria histórica, ajustada a las directrices de la pertenencia a la Corona de Aragón desde 1296 y al reino de Valencia desde 1304, y al papel providencial de los linajes dirigentes en sus acciones, militares y de gobierno. Sabemos que el apellido de estas familias va a adquirir un importante papel para la forja de la identidad de los grupos de poder ${ }^{41}$.

A tenor de lo expuesto por diversos especialistas, el origen catalán ${ }^{42}$ de algunos repobladores que colonizaron el territorio en el contexto de la represión de la revuelta mudéjar llevada a cabo por Jaime I facilitó la conquista del reino de Murcia por Jaime II. Hay que plantear la idea de que el origen catalán de algunos pobladores no es la única causa que permite explicar el paso de una soberanía a otra, y hay factores a tener en cuenta como la presencia de la cercana y poderosa nobleza castellana, frente a la menos numerosa y más frágil de la Corona de Aragón, el diferente modelo jurídico-institucional de la Corona de Aragón ${ }^{43}$ y la

Rafael, (coord.), La Mediterrània de la Corona d'Aragó, segles XIII-XVI. VII Centenari de la Sentència Arbitral de Torrellas, 1304-2004, XVIII Congrés d'Història de la Corona d'Aragó, 9-14 setembre, Valencia, Universitat de València, 2004, vol. 2, 2005, págs. 2061-2076.

${ }^{39}$ No fueron olvidados los fueros y privilegios recibidos en época castellana, como veremos más adelante.

${ }^{40}$ Estal, J.M. del, El reino de Murcia bajo Aragón (1296-1305). Corpus documental I/1, Alicante, Instituto de Estudios Juan Gil-Albert, 1985, doc. 9 (1296, abril, 29), págs. 120-121.

${ }^{41}$ BARRIO BARRIO, Juan Antonio, «La articulación de una oligarquía fronteriza en el mediodía valenciano. El patriciado de Orihuela. Siglos XIV-XV», Revista d'Història Medieval, 9 (1999), págs. 105-126. Sobre el papel de la onomástica y la heráldica en la forja de identidades de los grupos dominantes, vid. Bove, Boris, Dominer la ville. Prévôts des marchands et échevins parisiens de 1260 à 1350, París, CTHS, 2004, págs. 333-378.

${ }^{42}$ GuInot, Enric, Els fundadors del Regne de València. Repoblament, Antroponímia i llengua a la València medieval, 2 vols., Valencia, Tres i Quatre, 1999. FerRer MALLOL, María Teresa, Entre la paz y la guerra. La Corona Catalano-Aragonesa y Castilla en la Baja Edad Media, Barcelona, CSIC, 2005.

${ }^{43}$ BARRIO BARRIO, Juan Antonio, «La introducción del término Uniuersitas en las instituciones municipales del reino de Valencia», en NAscimiento, Aires A. y Alberto, Paulo F. 
plataforma marítima que permitía orientar la producción agrícola al mercado Mediterráneo ${ }^{44}$, algo que en Castilla resultaba inviable, etc. De hecho, uno de los privilegios ${ }^{45}$ más importantes que disfrutó la villa de Orihuela era la exención de todo gravamen sobre el trigo que salía de Orihuela con destino a cualquier villa, ciudad o puerto de la Corona de Aragón. Fue otorgado por Jaime II el mismo día que los oriolanos le prestaron juramento de fidelidad. En todo caso, lo cierto es que esta población de origen catalán facilitaba la tarea de acometer el desarrollo de una nueva burocracia administrativa, que se debía comunicar con el nuevo soberano y su cancillería, utilizando el catalán y el latín ${ }^{46}$ de forma indistinta como herramienta de diálogo político-jurídicoadministrativo entre el nuevo monarca y sus nuevos súbditos ${ }^{47}$.

En el mismo documento del juramento de fidelidad prestado por los oriolanos a Jaime II, se ponían las bases de una nueva identidad urbana y un nuevo discurso político. El documento ha sido redactado por el notario público de Orihuela, Pere Liminyana, y está escrito en catalán. Todo el vocabulario es nuevo, pero aparece perfectamente integrado en el orden político que se acaba de instaurar. Los cargos que presiden el acto son los jurados y responden al organigrama político propio de la Corona de Aragón e idéntico al vigente en la capital del reino de Valencia. El acto queda reflejado como una reunión del Consell de la villa, que era la base del municipio en la Corona de Aragón y fue celebrado en el lugar más solemne y sagrado de la localidad, la iglesia parro-

(coords.), IV Congreso Internacional de Latim Medieval Hispânico, Lisboa, Centro de Estudos Clássicos, 2006, págs. 191-201. Corrao ha puesto de manifiesto la importancia que tuvo en el sur de Italia el modelo urbano de la Universitas y las ventajas que para los centros urbanos suponía incorporarse al espacio público de la monarquía aragonesa, a su red urbana y a los circuitos de poder y de influencia del ámbito de la Corona de Aragón. CORRAO, Pietro, «La difficile identità delle città siciliane», en Chittolini, Giorgio y JoHAneK, Peter, (edits.), Aspetti e componenti dell'identità urbana in Italia e in Germania (secoli XIV-XVI), Bolonia-Berlín, Il Mulino-Duncker \& Humblot, 2003, pág. 105.

${ }^{44}$ BARRIO BARRIO, Juan Antonio, «La producción, el consumo y la especulación de los cereales en una ciudad de frontera, Orihuela, ss. XIII-XV», en ARÍZAGa Bolumburu, Beatriz, Solórzano TelecheA, Jesús Ángel, (Ed.). Alimentar la ciudad en la Edad Media, Logroño, Instituto de Estudios Riojanos, 2009, págs. 59-86.

${ }^{45}$ Corrao considera la codificación normativa de los privilegios, leyes y costumbres de una ciudad, uno de los elementos más importantes de la identidad ciudadana. CORRAO, «La difficile identità delle città siciliane», pág. 108.

${ }^{46}$ El oriolano Lope d'Espejo, autor de la obra Summa dei re di Napoli e Sicilia e dei re $d^{\prime}$ Aragona, estudió en su ciudad natal hasta los catorce años, adquiriendo en palabras suyas, una gran desenvoltura y elegancia en la composición de versos latinos, siendo su lengua materna el catalán. SPECHIO, Lope, Summa dei re di Napoli e Sicilia e dei re d'Aragona, edición crítica a cargo de Compagna, Ana Maria y CAPANO, Perrone, Napoli, Liguori, 1990, pág. 15.

${ }^{47}$ El castellano fue el único idioma utilizado en la documentación que recibió Orihuela de la monarquía castellana, debido a la imposición del castellano como única lengua oficial de la cancillería durante el reinado de Alfonso X. Mientras que en la época que Orihuela permaneció en la Corona de Aragón, el catalán y el latín se utilizaron de forma indistinta como los idiomas oficiales empleados en la cancillería Real y en la cancillería municipal de Orihuela. 
quial de San Salvador. Asimismo, la cúpula dirigente se presenta ante su nuevo rey, organizada como comunidad jurídica, como Universitas ${ }^{48}$.

La capital de la Gobernación de Orihuela tendrá en la frontera y en su pertenencia a la Corona de Aragón, así como en su autonomía y su capitalidad política, su esencia de ser, y buena parte de los esfuerzos políticos y diplomáticos se dirigirán a mantener y preservar esta posición dentro de la Corona de Aragón, sobre todo, a partir de su incorporación al reino de Valencia en 1304 , frente a las fuertes presiones que recibirá para limitar su autonomía municipal y su capacidad de actuación política, de los jurados de Valencia ${ }^{49}$ que, frente al resto de ciudades y villas del reino, presentarán a su urbe como madre protectora y benefactora de todos los habitantes del reino ${ }^{50}$.

Para Corrao, en Sicilia esta autonomía política se fundamentaba en la costumbre, los privilegios, la fiscalidad local e instituciones electivas, que formaban el núcleo de la identidad ciudadana, que permitía ejercer un control sobre el territorio, frente a las aristocracias feudales ${ }^{51}$. El grupo dirigente de la ciudad de Orihuela fue forjando una identidad urbana similar y en un contexto histórico común al de las urbes sicilianas, ya que su incorporación a la Corona de Aragón se realizó también a finales del siglo XIII.

Mientras que la lucha por su preeminencia religiosa, a través de la reivindicación de una sede episcopal propia, será otro pilar del discurso político del grupo dominante. Conceptos nuevos como Christianitas, Universitas, Corona de Aragón, frontera o nación se irán anclando en el discurso político de los centros urbanos del sur del reino de Valencia e irán forjando un discurso y una identidad política singular, dentro del escenario urbano de la Corona de Aragón.

${ }^{48}$ Vamos a tener en consideración en este trabajo la acepción de Universitas como una colectividad política. Niermeyer, J.F., Mediae Latinitatis Lexicon Minus, Leiden, 1976, III, pág. 1051. Para una explicación detallada del vocablo Universitas, vid. MiCHAUD-QUANTIN, Pierre, Universitas. Expressions du mouvement communautaire dans le Moyen-Age Latin, Paris, Libraire Philosophique J. Vrin, 1970.

${ }^{49}$ Las tensiones entre las ciudades «privilegiadas» bajo el dominio de un mismo soberano fue un fenómeno característico de las ciudades de la Corona de Aragón. La relación que mantenía la monarquía con sus ciudades, a través de la concesión de privilegios reales, creó una legislación local muy variada y numerosos centros de poder local «privilegiados». Era un sistema político que tenía en las ciudades y sus oligarquías ciudadanas uno de sus polos de poder, y en la multiplicación de los privilegios ciudadanos concedidos, el reforzamiento de las relaciones políticas entre la monarquía y las ciudades. CORRAO, «La difficile identità della città siciliane», págs. 100-101 y 103.

${ }^{50}$ Rubio Vela, Agustín, «Valencia: la conciencia de capitalidad y su expresión retórica en la prosa municipal cuatrocentista», Historia Medieval. Anales de la Universidad de Alicante, 13 (20002002), págs. 6-63.

${ }^{51}$ CORRAO, «La difficile identità della città siciliane», págs. 102. 


\section{ORIOLA SEMPER IN NOSTRO ET NOSTRORUM DOMINIO REMANERE. LA PLENA IDENTIFICACIÓN CON LA CORONA DE ARAGÓN}

El mismo día que los oriolanos prestaban juramento de fidelidad a su nuevo rey, Jaime II, recibían sendos privilegios del monarca, que sancionaban la pertenencia de la villa a la Corona de Aragón y el compromiso regio de no separar jamás a la urbe del patrimonio real:

...affectantes villam et castrum de Oriola semper in nostro et nostrorum dominium remanere et etiam retinere, conuenimus et bona fide promittimus per nos et omnes successores nostros vobis universis et singulis hominibus de Oriola et terminorum eius presentibus et futuris quod nunquam casu aliquo separabimus villam et castrum de Oriola nec separari faciemus, consentiemus aut permittemus a Corona Regni Aragonie et dominio nostro...52.

A partir de esta fecha, cada nuevo monarca debía comprometerse al principio de su reinado a no enajenar del patrimonio real a cada una de estas villas reales. A pesar de estos compromisos reiterados de los monarcas aragoneses, Alfonso IV el Benigno cedió importantes villas como Orihuela y Alicante a su hijo el Infante don Fernando. Esta acción demostraba que, por encima de los intereses de las oligarquías urbanas, predominaba la voluntad regia y las necesidades políticas y financieras de la Corona. Villas como Guardamar, Monforte o Murvedre (Sagunto) perdieron su autonomía jurídica y política, y pasaron a depender de Orihuela, Alicante y Valencia respectivamente tras la guerra de los dos Pedros en el siglo XIV. La villa de Elche perteneció durante la mayor parte de la Edad Media a diferentes señores, miembros de la familia real e incluso a la propia ciudad de Barcelona.

Por ello era crucial para las oligarquías urbanas mantener su independencia política y la vigencia plena de los privilegios reales que habían ido recibiendo de diferentes monarcas. Este tipo de privilegios constituía la esencia de la autonomía urbana ${ }^{53}$ de las ciudades valencianas de realengo ${ }^{54}$.

La Gobernación de Orihuela es una demarcación territorial singular en muchos aspectos. La primera característica es su posición fronteriza entre reinos, e incluso podemos decir entre Estados y civilizaciones, ya que fue frontera del reino de Valencia con el reino de Murcia, a partir de 1304, pero asimismo la marca que separaba en su límite meridional a la Corona de Aragón con la Corona Castellano-Leonesa y hasta 1492 estuvo situada en el espacio fronterizo que en Europa delimitaba la cristiandad occidental del Islam. La segunda peculiaridad es que en el corto periodo de tiempo que transcurre entre 1243 y 1304

\footnotetext{
52 EsTAL, J.M. del, El reino de Murcia bajo Aragón, doc. 20 (1296, mayo, 11), pág. 134.

${ }^{53}$ Max Weber consideraba que «la ciudad de verdad autónoma solo se encuentra en Occidente». Weber, M., La Ciudad, Madrid, La Piqueta, 1987, pág. 23.

${ }^{54}$ Por ello eran custodiados celosamente en los respectivos archivos municipales urbanos.
} 
cambió de dominio político en tres ocasiones. En 1243 y merced al Tratado de Alcaraz, villas como Orihuela, Alicante o Elche dejaban de pertenecer a Daral-Islam y se incorporaban dentro del reino de Murcia a la Corona CastellanoLeonesa en el ámbito de la cristiandad occidental. Un año después el tratado de Almizra, ratificaba y confirmaba dicha adscripción política. En 1296 Jaime II anexiona el reino de Murcia a la Corona de Aragón, por lo que la villa de Orihuela sigue perteneciendo al reino de Murcia, pero pasa a depender de un nuevo rey, Jaime II, soberano de los diferentes condados y reinos que conformaban la Corona de Aragón. En 1304 el tratado de Torrellas, una decisión salomónica acordada entre la Corona de Castilla y la Corona de Aragón, dividía el reino de Murcia en dos zonas utilizando el río de Segura como mojón delimitador entre ambos espacios. Para las localidades que seguían vinculadas al reino de Murcia, como la propia capital, suponía un retorno a la situación anterior a la conquista de Jaime II en 1296. El cambio más profundo se va a producir en aquellas tierras que en razón de lo acordado por el tribunal presidido por el rey de Portugal don Dionís y reunidos en la aldea aragonesa de Torrellas, quedaron desgajadas del reino de Murcia y siguieron perteneciendo a la Corona de Aragón, eso sí, a partir de Torrellas, bajo la legalidad jurídica que suponía la aceptación de la monarquía castellana de la nueva reordenación territorial.

Se iniciaba la tercera etapa para las tierras situadas en la frontera meridional peninsular de la Corona de Aragón. Cuando en 1296 los prohombres de la villa de Orihuela habían prestado solemne juramento de lealtad al rey Jaime II, lo habían hecho dentro de un marco político concreto, dentro del reino de Murcia. Lo acordado en Torrellas modificaba sustancialmente la situación anterior. Estos prohombres seguían siendo súbditos del mismo monarca, Jaime II, seguían perteneciendo a los dominios de dicho soberano dentro de la Corona de Aragón, pero quedaban en una situación de acefalía política, al quedar fuera de un marco regnícola, el propio de la organización administrativa de los reinos hispánicos y el que desde la creación del reino de Aragón se había difundido en todos los territorios conquistados por los monarcas aragoneses, como Mallorca o Valencia, por ejemplo.

Fue en estos cruciales y decisivos momentos de sucesivos cambios de dominación política cuando surge la necesidad y la oportunidad para la clase dirigente de la villa de Orihuela de articular un discurso político que les permita aprovecharse y sacar partido de su peculiaridad geo-histórica. Los ejes esenciales del discurso político, serán el orgullo de pertenencia a la Corona de Aragón y la reiteración de la fidelidad a la monarquía. Para Corrao, el primer elemento identitario de los centros urbanos sicilianos era la pertenencia al dominio regio ${ }^{55}$.

Al mismo tiempo, se defenderán las peculiaridades históricas de la villa, por un lado, su herencia islámica a partir de un legado que se va a mantener ${ }^{56}$, so-

\footnotetext{
55 CORRAO, «La difficile identità delle città siciliane», pág. 105.

${ }^{56} \mathrm{Va}$ a aparecer una expresión característica en la documentación para aludir a esta situación. «Como en tiempo de moros», va a indicar en diferentes cuestiones referidas a la organización del
} 
bre todo en lo referente a la tecnología hidráulica y a la organización jurídica del regadío y, por el otro, preservar los privilegios y mercedes recibidos en la época de dominación castellana y los decisivos que recibió de Jaime II en la etapa en que Orihuela permaneció en el reino de Murcia ${ }^{57}$.

Tras la anómala situación creada tras el Tratado de Torrellas, el primer esfuerzo de los oriolanos se encaminó a alcanzar la construcción de un reino propio, algo muy difícil de conseguir, pero que permitía plantear una dura negociación con la Corona en lo que podemos denominar la reconfiguración del pacto político inicial, rubricado en el juramento de 1296 . Frente a la pretensión desorbitada de los oriolanos de disponer de un reino propio, el rey optó de nuevo por una solución salomónica. No claudicó ante las exigencias que le realizaban, pero supo encontrar un término medio, ofreciendo la incorporación al reino de Valencia, que quedó consolidada y confirmada en 1308 con la recepción formal de los fueros de Valencia, pero creando para dichas tierras, a cambio, una nueva demarcación con capital en la villa de Orihuela, la procuración de Orihuela, convertida después con Pedro IV en Gobernación de Orihuela. Se constituía, por tanto, una demarcación político-administrativa, que si bien pasaba a pertenecer al reino de Valencia, lo hacía con un alto nivel de autonomía de la capital del reino, ya que dispondría de su propio Gobernador General, su propio Baile General, etc. Es decir, se sustentaba sobre una estructura administrativa regia, equiparable en importancia y competencias a la existencia en la capital del reino, aunque con una esfera territorial de actuación más reducida.

La demarcación eclesiástica va a jugar también un papel determinante en la construcción del discurso político, específico de la Gobernación de Orihuela. Durante los años en que la villa de Orihuela perteneció al reino de Murcia, la dependencia eclesiástica al Obispado de Cartagena-Murcia no planteaba ningún problema a los vecinos de la villa de Orihuela. Pero tras la sentencia de Torrellas, la villa de Orihuela quedó de forma definitiva incorporada a la Corona de Aragón, mientras que el reino de Murcia quedaba también vinculado de forma perpetua a la Corona de Castilla, pero no se producía una modificación

riego, las veredas, etc., que se mantenía igual que en la época de dominación musulmana. La expresión «el tiempo de los moros» equivalía también a reconocer la validez sobre determinados derechos sobre el agua. GLICK, Thomas F., Paisajes de conquista. Cambio cultural y geográfico en la España medieval, Valencia, Universitat de València, 2007, pág. 177.

${ }^{57}$ El decisivo privilegio de 1296 que permitía la extracción de trigo de Orihuela, libre de impuestos y con destino a cualquier puerto de la Corona de Aragón entró en clara contradicción con los privilegios que disfrutaba la ciudad de Valencia, como capital del reino de Valencia y que afectaron a la villa de Orihuela a partir de su incorporación al reino valentino. Pese a ello, las autoridades oriolanas defenderán con tesón la vigencia de este privilegio durante toda la Edad Media, en una tenaz pugna mantenida entre las autoridades locales de Orihuela y sus homónimos de Valencia. Sobre esta cuestión, vid. Rubio Vela, Agustín, «Valencia y el control de la producción cerealista del reino en la Baja Edad Media. Orígenes y planteamientos de un conflicto», Aragón en la Edad Media. Demografía y Sociedad en la España bajomedieval. Seminario Historia Medieval, Zaragoza, Universidad de Zaragoza, 2003, págs. 38-40. 
en la adscripción eclesiástica de las parroquias de las localidades que ahora conformarían la procuración de Orihuela. A partir de este momento, las tensiones de las villas de la Gobernación de Orihuela con el obispado van a ser constantes y se van a convertir en uno de los referentes temáticos recurrentes en el discurso político de los grupos dirigentes urbanos.

Estos tres principales argumentos, posición territorial fronteriza y necesidad de un esfuerzo bélico continuo, peculiaridad geo-histórica como demarcación territorial singular y la posición de secular enfrentamiento con el obispado ${ }^{58}$, marcan el eje de un discurso político, en cuya armazón retórica se incorporarán elementos como la feracidad productiva de su huerta.

Todas estas cuestiones confluyen en una estrategia que la oligarquía oriolana manejará entre la prudencia, la capacidad de negociación o pacto y la osadía más descarnada, con un objetivo principal, conseguir las mayores ventajas económicas, políticas y sociales para los linajes dominantes y, por extensión, para todos los vecinos del término. Para ello se reforzará la lealtad a la monarquía a la Corona de Aragón, a todos los símbolos propios de la Corona, iconografía, lengua, cultura, religiosidad, etc. Todo ello con una estimulación en paralelo y una retroalimentación a través de la insistencia en el enfrentamiento con el rival castellano, con la creación de un imaginario propio, asociado a contextos bélicos fronteros, tensiones eclesiásticas, banderías nobiliarias, etc. Los rivales serán los castellanos en general, los de la nación castellana y los murcianos en particular, el Adelantado del reino de Murcia, la ciudad de Murcia, el propio reino de Murcia y el Obispo de Murcia, en un discurso que se retroalimenta de la elaboración que el «otro» hace a su vez de su propio discurso, al otro lado de la frontera ${ }^{59}$.

El mensaje político se sustenta en el arte de la retórica ${ }^{60}$ que va a ser puesto al servicio de la clase gobernante, servido con puño de hierro o guante de seda, al socaire de las circunstancias y las necesidades de cada momento. Esta retórica y el ars dictandi lo van a aprender los notarios oriolanos a través de los modelos retóricos que van a encontrar en la documentación de cancillería recibida en

${ }^{58}$ Podemos plantear una posible disfunción identitaria, frecuente en las ciudades italianas, que en su identidad urbanística tenían en su catedral uno de los elementos identificativos del paisaje urbano, dedicando dispendios del erario público en sus obras. CORRAO, «La difficile identità della città siciliane», pág. 120. Este elemento identificado entre identidad urbana y catedral no estuvo presente en ciudades como Orihuela, que carecían de catedral y que estaban vinculadas a una diócesis ubicada en un reino extranjero. Siendo frecuentes las protestas del grupo dirigente por los impuestos que tenían que pagar y que se destinaban a la reparación y mejora del edificio de la catedral ubicada en la ciudad de Murcia. En este caso, el edificio catedralicio actuaba como resorte de rechazo, concentrando la identificación edilicia religiosa, en la principal parroquia de la ciudad, que en Orihuela era la Parroquia del Salvador, futura sede de la Catedral de Orihuela en el siglo XVI.

59 Jiménez AlCÁzAR, Juan Francisco, «El regno de Murçia que yo gané del rey de Aragón», monográfico Vivir en el Alicante Medieval, Canelobre, 52 (2007), págs. 176-191.

60 ARTIFONI, Enrico, «Retorica e organizzazione del linguaggio politico nel Duecento italiano», en CAMmAROSANO, Le forma della propaganda politica, págs. 157-182. 
las oficinas del palacio municipal de Orihuela y de los que van a extraer con rapidez los modelos y enseñanzas necesarias para sus propios escritos. Estos documentos redactados por los notarios de la corte real de la cancillería de la Corona de Aragón van a ser la fuente de inspiración para el desarrollo de la lengua catalana en la Baja Edad Media, en todas sus vertientes, cancillería municipal, notariado urbano, literatura, etc. Era una koiné lingüística que, con una grafía propia y utilizando un lenguaje retórico, político y literario común, facilitaba la integración ideológica e intelectual de las clases dirigentes urbanas del sur del reino de Valencia en la Corona de Aragón.

Las oligarquías dirigentes van a reiterar de forma constante el papel «militar» fundamental que desempeñaban, recordando en todo momento los sacrificios realizados al servicio de la Corona de Aragón, como en un memorial de 1449 enviado al rey en el que las autoridades de Orihuela invocaban los esfuerzos y padecimientos soportados por sus antepasados para poder obtener los privilegios reales, poniendo como ejemplo un relato épico situado en la guerra de los dos Pedros, en el que narraban cómo de siete mil combatientes que se encontraban en la ciudad de Orihuela asediados durante gran tiempo, tanto por el rey don Pedro de Castilla como por el infante de Granada, quedaron solo quinientos supervivientes, en una situación de tan grave penuria que de pura hambre no encontraron nada para comer ni bestias ni otras cosas, teniendo que comer carne de hombre, actuación que consideraban inhumana, «per que nos lig del setge de jherusalem a ença vasallas per senyor aver fet tant grans serveys e pesats tals martiris e congoxes com los d'Oriola an fet per servey de la Corona d'Arago» ${ }^{61}$. Este tipo de expresiones que, por otra parte, son frecuentes en la documentación oriolana del siglo XV, muestra la necesidad de una afirmación ritual de su identidad colectiva, apelando a expedientes como la búsqueda de una herencia ancestral y la celebración y reivindicación de un pasado mítico en nombre de la historia de su ciudad, recurriendo como en el ejemplo anterior a grandes episodios de la Historia, como el asedio de Jerusalén ${ }^{62}$. Es una referencia clara a la Historia de Orihuela, escrita en el siglo XV, época en la que el estudio del pasado se convirtió en un medio para expresar, canalizar y desarrollar el sentimiento de conciencia nacional y la inquebrantable lealtad a la Corona de Aragón ${ }^{63}$.

${ }^{61}$ AHO, Contestador, n. ${ }^{\circ} 28$, ff. 66v. (1449, mayo, 22).

${ }^{62}$ Pedro IV utilizaba en sus discursos el ejemplo del asedio que sufrió Jerusalén, durante el reinado del rey de Judá, Ezequías, que fue atacado por Senaquerib, rey de Asiria. Pedro IV interpretaba la salvación de Jerusalén gracias a las disposiciones de su rey y a la gracia de Dios. Cawsey, Suzanne F., Reialesa i propaganda. L'eloquiència reial i la Corona d'Aragó, c. 1200-1450, Valencia, Universitat de València, 2008, págs. 102-103. En el discurso de las autoridades oriolanas, podemos interpretar este recuerdo al asedio de Jerusalén, como una alusión a las buenas disposiciones, tanto de los gobernantes oriolanos como de los reyes de la Corona de Aragón.

${ }^{63}$ Ernest Renan, en su definición de nación, decía «Una nación es, por tanto, una gran comunidad solidaria, sostenida por el sentimiento de los sacrificios que se han hecho y de los sacrificios que aún se está dispuesto a hacer». El grupo dirigente de Orihuela utilizaba este criterio 
ATORGAT PER UTILITAT E BON STAMENT DE LA COSA PÚBLICA D'AQUEXA VILA QUI ÉS SITUADA EN FRONTERA DE CASTELLA E DE MOROS. LA IDENTIDAD Y EL DISCURSO SOBRE LA FRONTERA

En el sur del reino de Valencia en la Baja Edad Media, la frontera fue uno de los elementos más característicos en la organización social del espacio, por el peligro exterior de la amenaza granadina y la presión castellana. Además, para las localidades con población mayoritaria cristiana, la inquietud que provocaba la frontera interior por la presencia de las comunidades mudéjares en los señoríos de la Gobernación representaba un argumento ideológico de peso para sustentar y reforzar la consolidación de oligarquías locales armadas y militarizadas $^{64}$.

El desarrollo de la frontera medieval peninsular a partir del siglo XIII es la consecuencia de la consolidación de dominios territoriales llevado a cabo por las potencias implicadas, Corona de Castilla-León, Corona de Aragón y reino Nazarí de Granada. El establecimiento de una línea fronteriza suponía la aceptación y reconocimiento mutuo de cada una de las partes de dicho contorno fronterizo y el asumir un statu quo territorial a partir de un determinado momento.

Torres Delgado plantea el establecimiento de la frontera nazarí como fenómeno paralelo a la creación del Estado granadino y llevado a cabo desde 1246 hasta 1260, fecha en que, a su juicio, queda realmente establecida la frontera del reino nazarí de Granada ${ }^{65}$. Acción que lleva pareja la creación de una frontera similar en territorio castellano, a la vez que entre castellanos y aragoneses se ha fijado desde el Tratado de Almizra una primera frontera. La primera consecuencia es la creación de la frontera, que será estable pero no inamovible. Torres Delgado, en esta línea, ha elaborado una interesante cronología que muestra la evolución de la frontera nazarí granadina desde su primera fase de establecimiento (1246-1260), hasta su desaparición en $1492^{66}$.

La historiografía que se ha ocupado del estudio de las identidades nacionales, territoriales y fronterizas ha desdeñado o minusvalorado la posición de los reinos medievales ante la toma de conciencia en cada una de estas cuestiones. Se ha objetado que la identidad nacional surgió con claridad a partir del siglo XIX, sobre la base de principios como la precisa y definida territorialidad y las fronteras de una nación ${ }^{67}$, o a través de los postulados de Anderson, que afirmaba que gracias a los modernos y eficaces sistemas de comunicación, verbi-

para cimentar la unidad de la comunidad en el contexto de una comunidad más amplia, la Corona de Aragón. Cit. en SCHUlze, Hagen, Estado y nación en Europa, Barcelona, Crítica, 1997, pág. 87.

${ }^{64}$ El uso de armas se considera un elemento distintivo respecto al mundo rural y uno de los signos distintivos de la libertad ciudadana. Bordone, Uno stato d'animo, pág. 9.

${ }^{65}$ Torres Delgado, Cristóbal, «El territorio y la economía», en Historia de España Menéndez Pidal, Madrid, Espasa Calpe, tomo VIII, pág. 509.

${ }_{66}$ TORRES DELGADO, «El territorio y la economía», págs. 509-511.

${ }^{67}$ Hermet, Guy, Histoire des nations et du nationalisme en Europe, Paris, Seuil, 1996. 
gracia la producción impresa masiva, se facilitaba la homogeneización cultural e ideológica de una nación ${ }^{68}$. Hermet argumenta que es difícil documentar la conciencia colectiva de las poblaciones medievales, privadas de acceso a la escritura y prácticamente sin contacto los unos con los otros ${ }^{69}$. Estas aseveraciones parten, una vez más, de un profundo desconocimiento de la documentación y la sociedad medieval. Los archivos locales de los municipios europeos conservan miles de testimonios que permiten reconstruir los sistemas identitarios de los dirigentes urbanos de las villas y ciudades europeas al menos desde el siglo XIII. Por otra parte, el pretendido analfabetismo de toda la sociedad medieval debería empezar a ser cuestionado, ya que además de la gente que podía llegar a leer, el resto de los habitantes de las ciudades eran informados de forma puntual de las disposiciones normativas o de otras noticias a través de la transmisión oral de la información. La supuesta falta de contacto de unos con otros es otro tópico falso sobre la Edad Media. El apogeo del mundo urbano a partir del siglo XI y el desarrollo de rutas de peregrinación como el camino de Santiago convirtieron a los europeos en una sociedad viajera y comunicada. Los caballeros-guerreros, los comerciantes, los marinos, los artesanos o los mensajeros de las ciudades se desplazaban de unos lugares a otros en el desempeño de su actividad y se ponían en contacto con gentes que vivían en lugares alejados, con los que intercambiaban conocimientos, ideas, tecnologías, etc. ${ }^{70}$. En este sentido, fue decisiva la difusión del papel como material escriturario y el potente desarrollo de la relación epistolar entre ciudadanos a nivel privado y entre los diversos centros de poder a nivel público. Como colofón a estas relaciones epistolares en los siglos finales de la Edad Media se produjo el origen de las relaciones diplomáticas entre los diferentes centros de poder, con el envío de sus mensajeros o embajadores que permitían poner en contacto ideas y corrientes de pensamiento entre unas ciudades y otras, sin olvidar el papel de las cortes y parlamentos medievales, que también favorecieron estos intensos contactos entre los representantes de las oligarquías dirigentes de los centros urbanos europeos.

Creo que a finales de la Edad Media se forjaron de forma seminal los primeros conceptos sobre frontera y nación, pero ideas y términos que eran desarrollados por las clases dirigentes y que tenían una incidencia difícil de mensurar entre el resto de las capas sociales y, siguiendo postulados como los de Anderson, la principal aportación del siglo XIX es la plena madurez y la consolidación de las ideas sobre nación, territorio o frontera entre las capas dirigentes y

\footnotetext{
68 AnDERSON, B., Comunidades imaginadas: Reflexiones sobre el origen y la difusión del nacionalismo, México, Fondo de Cultura Económica, 2005.

${ }^{69}$ Hermet, Histoire des nations, pág. 41.

${ }^{70}$ En descargo de Hermet se puede alegar que el fenómeno de la transmisión de la información en la Edad Media sigue siendo un tema poco investigado. Un congreso reciente se ha ocupado de esta novedosa cuestión. Boudreau, Claude, Fianu, Kouky, Gauvard, Claude y HÉBert, M., Information et société en Occident à la fin du Moyen âge, París, Publications de la Sorbonne, 2004.
} 
la posterior asimilación, con mayor o menor lentitud, por las masas populares, de valores como nación, patria, etc.

Los procesos de construcción de identidades han sido más intensos y prolongados en el tiempo de lo que algunos historiadores han llegado a vislumbrar. Lo que en principio fue una conciencia de identidad que podía quedar limitada a las fronteras de una ciudad, se extendió en adelante hacia la abstracción, a las fronteras de un Estado que, por otra parte, la mayoría de los habitantes no habían visto jamás ${ }^{71}$.

Para Rodríguez López, el término frontaria es utilizado de forma exclusiva para designar los límites territoriales entre cristianos y musulmanes y nunca las franjas limítrofes que separaban Castilla de los demás reinos cristianos $^{72}$. Para la mayoría de autores que se han ocupado de estudiar la frontera entre el reino Nazarí de Granada y el reino de Castilla, el análisis de la frontera se circunscribe de forma exclusiva a dicha demarcación fronteriza ${ }^{73}$.

En el reino de Valencia, la Gobernación de Orihuela fue un espacio fronterizo o demarcación natural creada a partir de la firma del tratado de Torellas en 1304. En este territorio, el término y el concepto frontera tienen igual aplicación para la frontera con los musulmanes como para la frontera con los cristianos del reino castellano de Murcia.

En un documento de Pedro IV dirigido a las autoridades de la villa de Orihuela concediendo un privilegio sobre la posesión de caballo armado de sus habitantes, el monarca indica con precisión la posición de frontera de sus habitantes respecto a los enemigos musulmanes del reino nazarí de Granada y el reino de Castilla. Este texto recoge una precisa definición de la frontera que afectaba a la villa de Orihuela. La primera alude a los musulmanes del reino nazarí de Granada y la segunda, a la frontera con el reino de Murcia perteneciente a la Corona de Castilla.

Com per algunes causes e rahons justes e com hauents memoria de molts e diverses agradables serveys a nos feits per los habitants en la vila de Oriola com encara esguardants que la dita vila es situada en frontera axi dels enemichs de la fe xristiana ço es de la morisma de Granada com encara del reyalme de Castella e que necessaria cosa a la poblaçio guarda e defensio de la dita vila e dels termens de aquella que los habitants en aquella e en sos termens no solament sien per nos e per lo dit nostre primogenit e per los oficials nostres e seus regits e tractats justament mas encara favorable e graciosa ${ }^{74}$.

${ }^{71}$ Messadié, G., Historia del antisemitismo. Buenos Aires, Javier Vergara, 2001, pág. 221.

${ }^{72}$ RODRíguez LÓPEZ, A., La consolidación territorial, pág. 259.

${ }^{73}$ Criterio también recogido en un libro de reciente aparición. RodríGuez MolinA, J., La vida de moros y cristianos en la frontera, Alcalá, Alcalá la Real, 2007. El título en su expresión genérica debería aludir a todas las fronteras que se desarrollaron en la península ibérica, incluidas las que afectaron a territorios de la Corona de Aragón. El desarrollo del libro se centra de forma exclusiva y muy especialmente en la frontera «entre Castilla y Granada» (Vid. Contraportada).

${ }^{74}$ AMO, Libro becerro, f. 94 r-v. (1364, diciembre, 20). 
En un documento de 1382, se precisa la peculiar situación de frontera de la villa de Orihuela: «Attressí como Oriola sie hedificada en loch de frontera de moros, hoc encara en frontera de castellans més que altre loch alcú del regne e senyoria del senyor rey d'Aragó» 75 .

En un privilegio de Juan II emitido más de cien años después del privilegio de Pedro IV que recogía una precisa definición de la frontera de la Gobernación de Orihuela, se detalla una definición similar e incluso más explicita.

Nos encontramos en la recta final de la Edad Media en 1469. Han pasado doscientos años desde que el territorio fue pacificado por Jaime I en la campaña que realizó en el reino de Murcia para sojuzgar la revuelta mudéjar que había estallado en Andalucía y en el reino de Murcia. En algunos aspectos no había cambiado casi nada y el statu quo se mantenía en la gobernación de Orihuela, con una frontera que desde las importantes modificaciones de 1304 con el Tratado de Torrellas, seguía perfilando una situación de triple frontera para la población cristiana de las localidades de realengo como la ciudad de Orihuela, con la numerosa población mudéjar que residía en los núcleos señoriales de la propia Gobernación en zonas con gran densidad de población como el valle de Elda, con la presión del cercano reino nazarí de Granada y con la frontera directa en torno al río Segura con el reino castellano de Murcia.

Nós, don Joan, etc. Segons per part de vosaltres, amats e feels nostres los jurats e prohòmens de la nostra ciutat d'Oriola, nos és stat humilment significat, la dita ciutat e governació d'Oriola que és dellà Saxona és en la frontera de Castella e de Granada e poblada de molts lochs de mores e christians que són de senyoria de barons e cavallers, de què s'esdevé molt sovint que en los límits de la dita governació entrent gents per fer dans als poblats en aquella molt poderosament ${ }^{76}$.

Unos pocos años antes, en febrero de 1460, la tensión entre las autoridades de la ciudad de Orihuela, capital de la gobernación, era extrema ante la situación que se estaba viviendo en el cercano valle de Elda, con una elevada población mudéjar, ante la posibilidad de establecer una morería real en la villa cristiana de Monforte, lo que podía conllevar la despoblación y el abandono del lugar de los cristianos y, a juicio de los regidores oriolanos, poner en peligro la integridad física de la población cristiana de la Gobernación de Orihuela77. Así lo exponían en el memorial que preparaban para a través de un mensajero hacer llegar a Juan II sus temores.

${ }^{75}$ Ferrer I Mallol, María Teresa, Organització i defensa d'un territori fronterer. La Governació d'Oriola en el segle XIV, Barcelona, CSIC, 1990. Doc. 210 (1382, mayo, 12), pág. 516.

${ }^{76}$ ARV, Real, reg. 291, ff. 135v-136r. (1469, junio, 12 ).

${ }^{77}$ BARRIO BARRIO, Juan Antonio, «La difícil convivencia entre cristianos y musulmanes en un territorio fronterizo. La gobernación de Orihuela en el siglo XV», Sharq Al-Andalus, 13 (1997), págs. 9-26. 
Item informara la dita majestat e notificara aquella com la vall d'Elda segons sa majestat ha vist sia tota poblada de moros la qual per esser contigua ab Regne de Castilla e quasi de Granada continuament en aquella venen adalids del dit Regne de Granada los huns per pasar moros del dit Regne e altres per matar robar e cativar xristians per los quals adalids es stat vist esser fets en la dita vlla molts dans...per causa del loch de Monfort qui es poblat de xristians qui esta en lo mig del dit vall qui ja en lo temps que aquesta terra fon recuperada e conquistada de moros se dona horde lo dit loch restas en la dita vall poblada de xristians per ço que los moros del dit vall no poguesen cobrir o donar obra que moros de Granada venguesen per fer los dits dans... ${ }^{78}$.

El texto refleja de forma elocuente una amenaza real, aunque a lo mejor algo exagerada por parte de las autoridades. Pero nos interesa resaltar de este documento la expresión de una identidad y conciencia desarrollada por la oligarquía dirigente oriolana sobre la situación fronteriza de un territorio, la gobernación de Orihuela, y, sobre todo, de las ciudades, villas y lugares poblados por cristianos que tenían que coexistir con señoríos con una elevada población mudéjar. Todos estos diferentes aspectos confluyen en la elaboración de una identidad colectiva, en la consolidación de una comunidad cristiana ${ }^{79}$, sobre las bases de unos antepasados conquistadores que son glorificados por haber «recuperada e conquistada de moros... aquesta terra», y sobre la permanente existencia de una frontera que requiere de sucesivos esfuerzos bélicos por parte de los individuos que sustentan y reafirman esta comunidad.

En el Cuatrocientos, los miembros de las oligarquías urbanas son los descendientes de los antiguos combatientes de la frontera, que mantienen en su memoria las hazañas de sus antepasados y de ellos mismos contra los musulmanes granadinos y contra los castellanos, como se jactan de recordar en sus peticiones de privilegios a la Corona.

Todo este programa de construcción de un aparato propagandístico para el ejercicio del poder en el ámbito local y que llevaba implícito la elaboración de un discurso político que reafirmaba la identidad de la urbe cristiana, era construido y reafirmado por la elite dirigente, que, tras la conquista cristiana, fue elaborando una identidad que afirmaba y reiteraba su hegemonía, la necesidad de sus servicios y la gratitud que debía emanar hacia estos linajes que eran los detentadores de la memoria y la historia de la nueva comunidad cristiana y que estaba integrada plenamente en la Corona de Aragón.

${ }^{78}$ AHO, Contestador, n. ${ }^{\circ} 31$, ff. 29r-v. (1460, febrero, 25).

${ }^{79}$ Sobre la elaboración y reforzamiento de una identidad cristiana en la Corona de Aragón, vid. Evangelisti, P., «Christus est proximus noster. Costruzione dell'identità comunitaria e definizione della infidelitates in Arnau de Vilanova e Ramon Llull», Studia Lulliana, 45-46 (2005-2006), págs. 39-70. 
DESFAVORINT ALS DE LA NAÇIÓ CATALANA. LA NACIÓN Y LA MEMORIA HISTÓRICA

El tratado de Torrellas de 1304 y su corolario el acuerdo de Elche de 1305 van a tener como principales consecuencias la partición del reino de Murcia, el retorno del reino de Murcia fragmentado a la Corona de Castilla y la incorporación de una parte del reino de Murcia al reino de Valencia.

Con ello se ponía fin, de forma definitiva, a la trayectoria del reino de Murcia en la Corona de Aragón, y era necesario reajustar la organización de los dos territorios en los que había quedado partido el reino de Murcia. La capital del reino, la ciudad de Murcia y las localidades que quedaron asignadas a la Corona castellano-leonesa tuvieron que retornar a los principios rectores anteriores a 1296 y que correspondían a lo promulgado durante los reinados de Fernando III, Alfonso X, Sancho IV y Fernando IV. En los territorios al norte del río Segura y que siguieron perteneciendo a la Corona de Aragón, correspondía un reajuste en otra dirección.

Esta nueva orientación, que ha sido calificada como de tercera vía ${ }^{80}$, forjó una identidad política promovida desde Orihuela, que se alejaba de su pasado murciano, pero sin integrarse de forma completa en su nueva adscripción valenciana, a la vez que preservando de su legado castellano, privilegios, mercedes, honores e incluso oficialías como el de sobrecequiero, que a su vez había sido creada bajo el paradigma del legado islámico. El denodado esfuerzo que realizaron los oriolanos entre 1304 y 1308 para poder disfrutar de un código legislativo propio, diferente a los fueros de Valencia, denominado los fueros de Orihuela, pero que se basaba en el primitivo proyecto legislativo de Jaime II de impulsar un código jurídico para su reino de Murcia, los fueros de Murcia ${ }^{81}$, fue infructuoso, ya que todas las villas de la Gobernación de Orihuela recibieron en 1308 los fueros del reino de Valencia como su principal ordenamiento jurídico. A pesar de ello, la voluntad de independencia política de los oriolanos respecto a la capital del reino, Valencia, se plasmó en una amplia serie de singularidades legislativas, judiciales y políticas, que forjaron un discurso político y una identidad política, propia y específica, que había dejado de ser murciana, pero que nunca llegó a ser del todo valenciana, aunque en lo genérico los oriolanos mostraron en su discurso político su plena adhesión, primero a la Corona de Aragón y después al reino de Valencia, dentro de una identidad más amplia que fue denominada por los propios oriolanos de la nación catalana.

${ }^{80}$ Cabezuelo Pliego, J.V., «La gobernación de Orihuela en el paso del dominio castellano al catalano-aragonés», en MiLláN, Fronteras e identidades en el sur valenciano, págs. 15-27.

${ }^{81}$ ESTAL, J.M. del, «El fuero y las Constitutiones regni Murcie de Jaime II de Aragón (1296 y 1301). Edición y estudio histórico», Anales de la Universidad de Alicante. Historia Medieval, 8 (199091), págs. 19-56. 
Se ha asumido de forma tradicional la idea de que Estados y naciones tienen un origen incierto, si bien está muy extendida la doctrina del conflicto ${ }^{82}$ como elemento dinamizador y fortalecedor de identidades y conciencias específicas, en el seno de una común y global, la cristiandad occidental. Durante los siglos XIV y XV, los graves enfrentamientos bélicos entre estados condujeron a la construcción de un aparato propagandístico al servicio de las monarquías que demonizaba al rival, los ingleses en la Guerra de los Cien Años, verbigracia, presentando a los franceses como cobardes y afeminados a los ojos de los ingleses, construyendo estereotipos nacionales muy negativos sobre los rivales. De esta forma, todo un pueblo, visto por un extraño, era condenado a través de unas pocas palabras, de dos o tres adjetivos peyorativos. Su misma identidad y sus características eran reconocidas por otros a los que, a su vez, se les imponía otra identidad. La forma en que una nación era vista por otra influía en la creación de un sentido de conciencia nacional ${ }^{83}$. En la península ibérica fue decisivo el conflicto que enfrentó a castellanos frente a aragoneses en la guerra de los dos Pedros y que tuvo en la provincia de Alicante uno de sus principales escenarios de combate. La guerra fue uno de los catalizadores de la formación de identidades propias, urbanas o nacionales. Afrontar un peligro exterior aceleraba la cohesión alrededor de un territorio, de una lengua, de una religión ${ }^{84}$, en pocas palabras, de una civilización. La existencia de símbolos nacionales servía para reforzar esta cohesión.

En este contexto internacional se impuso en la ciudad fronteriza de Orihuela la necesidad de elaborar un discurso político para utilizar frente a los rivales exteriores y como factor de reafirmación de la identidad y los derechos de la comunidad local. Es un rearme ideológico permanente que se alimenta de los conflictos reiterados que mantienen las autoridades locales con el Obispo de Cartagena y la vecina ciudad de Murcia. En la propaganda política utilizada por los gobernantes oriolanos en su sempiterno enfrentamiento con el Obispado de Cartagena y con la ciudad de Murcia, se desplegaron estrategias cercanas a las utilizadas por las grandes potencias políticas en los enfrentamientos bélicos. La propaganda anticastellana, la difamación del adversario y el envío de embajadores ${ }^{85}$ son algunos de los gestos utilizados habitualmente por las autoridades oriolanas contra el Obispo o las autoridades civiles castellanas.

En las crónicas, profecías y canciones de carácter propagandístico escritas por ingleses y franceses en el contexto de la Guerra de los Cien Años, con espí-

${ }^{82} \mathrm{La}$ guerra actuaba como elemento que incentivaba el desarrollo de la propaganda. ARChETTI, «Le forma della propaganda politica alla fine del Medioevo», Nuova Rivista Storica, LXXX-3 (1996), pág. 682.

${ }^{83}$ Beaune, C., Naissance de la nation France, París, Gallimard, 1985.

${ }^{84}$ En una obra reciente, se defiende la relación entre religión y construcción de un sentimiento nacional. Hastings, Adrian, The Construction of Nationhood. Ethnicity, Religion and Nationalism, Cambridge, Cambridge University Press, 1997.

${ }^{85}$ Eran estrategias habituales de legitimación en contextos de conflicto bélico o político. ARCHETti, Le forma della propaganda politica, pág. 683. 
ritu tanto laudatorio como difamatorio, se utilizaban simbolismos florales y animales para personificar virtudes y defectos. Para definir y calificar a otras naciones, los hombres del siglo XIV recurrían a flores en general y a la flor de lis en particular, y a animales como leones, leopardos, lobos o águilas. El lobo simbolizaba la crueldad, la injusticia y la ferocidad. Por ello las autoridades de Orihuela escogieron a este animal como símbolo para difamar al Obispo de Cartagena-Murcia al que definían en un memorial como un lobo rapaz. Refiriéndose al Obispo decían: «que ell mentia e que era lop rabat e altres coses per les quals la desamistat es stada pus encarnada que no era» ${ }^{86}$. En realidad, en los territorios europeos que compartían gentes de diferente etnia o lengua, los conflictos eclesiásticos eran uno de los motivos más recurrentes de enfrentamientos y, en particular, todo lo referido a provisión de vacantes eclesiásticas ${ }^{87}$, pugnando cada grupo de presión por el nombramiento de alguien étnica o lingüísticamente cercano.

En este debate se forjó la utilización del término «nación», en concreto, el término «nación catalana», utilizado en la primera mitad del siglo XV por las autoridades locales de Orihuela y empleado como elemento excluyente, de consideración de lo propio y de diferenciación frente al enemigo, lo que refuerza todavía más la entidad y el valor del concepto nacional, en el periodo previo a la formación de los Estados Modernos ${ }^{88}$ : «Item senyor que no solament per lo dit bisbe que a present es. E encara per tots los passats qui continuament son castellans... E han acostumat favorir als de naçio castellana desfavorint als de la naçio catalana ${ }^{89}$.

En este discurso propagandístico, la correspondencia de las autoridades locales con la Corona está jalonada de referencias a la feracidad de la huerta de Orihuela, a su proverbial producción cerealista que motivaba la repoblación y el crecimiento de la localidad, llegando a poner por escrito en una misiva de 1449 el adagio popular «ploga o no ploga blat a Oriola», recogido luego en

${ }^{86}$ AHO, n. ${ }^{\circ} 21$ f. 133r. (1433, diciembre, 15).

${ }^{87}$ En 1404 Enrique III ordenó que no fuese recibido como Arzobispo de Toledo don Pedro de Luna, por su origen aragonés. Archivo de la Catedral de Toledo, A.8.I.1.1. (1404, febrero, 25). Enrique III en su rechazo al nombramiento de don Pedro de Luna utilizaba un argumento que ya había esgrimido en las Cortes de Madrid de 1396, en las que se había quejado del perjuicio que se podía producir en los nombramientos que recaían en personas no naturales de los reinos. Esta tensión no era nueva y expresaba la resistencia de los reyes castellanos al acceso a los beneficios eclesiásticos de las diócesis del reino a los extranjeros. Estos planteamientos ya habían sido manifestados durante el reinado de Enrique II en las Cortes de Burgos de 1377.

${ }^{88}$ La minoría dirigente de Aragón consiguió imponer las bases del estado moderno, a través de cuatro acciones sustentadas en: A) La fijación del espacio aragonés. B) Personalidad de las instituciones propias. C) Definición de la nacionalidad y D) Impulsar un sentimiento colectivo. SESMA MUÑOZ, J.A., «El sentimiento nacionalista en la Corona de Aragón y el nacimiento de la España moderna», en RUCQUOI, A.(Ed.), Realidad e imágenes del poder, Valladolid, Ámbito, 1988, págs 215-231.

${ }^{89} \mathrm{AHO}$, n. $^{\circ} 21$ f. 132r. (1433, diciembre, 15). 
castellano por Viciana en su Crónica del siglo XVI o por los viajeros extranjeros que en el siglo XVIII visitaron Orihuela y repitieron elogios y dichos populares que ya circulaban por escrito en el siglo XV.

E sian informats verídicament que la orta de la dita vila sia un de les principals membres d'aquella, la qual sosté la maior part de la dita vila e és causa de la populació e augmentació d'aquella, e huy no sia cultivada ne conreada, segons fahia en temps passat quant era pus poblada axí de xristians com de moros ${ }^{90}$.

En 1433 las autoridades de Orihuela consideraban una grave provocación para los oriolanos el hecho de que todavía se encontraran en la Catedral de Murcia los ingenios con que se derribaron los muros y las torres de Orihuela en la guerra de los dos Pedros. Para los oriolanos que tenían que acudir a Murcia a resolver cuestiones relacionadas con la jurisdicción del Obispo, les resultaba una grave afrenta tener que contemplar dichos artilugios ${ }^{91}$.

Item lo dit bisbe ha introduyt hun dret appellat lo quint delmer de cascuna parroquia de son bisbat lo qual fa exhigir e llevar de les parts d'Aragó per obrar la seu en Castella qui es en la dita ciutat de Murcia e encara huy son los trabuchs e engenys ab los quals lo rey don Pedro derroca los murs e torres de la dita vila d'Oriola...

Era una historia de la ciudad y de las principales familias de la misma, reinventada y reinterpretada ${ }^{92}$, ajustando cada suceso histórico a su adecuada y providencial trayectoria, como protagonistas de un recorrido singular, que iba desde la conquista a los moros y la cristianización del espacio ${ }^{93}$, la resistencia a

90 ARV, Real, reg. 50, ff. 16v-17r. (1431, agosto, 1).

91 AHO, n. ${ }^{\circ} 21$ f. 117v. (1433, diciembre, 15).

${ }^{9}$ Hemos encontrado un ejemplo notable de reelaboración de la memoria histórica de los linajes de la ciudad en una obra manuscrita sobre la ciudad de Orihuela terminada de elaborar en torno al año 1620. En esta primera crónica histórica sobre la ciudad de Orihuela, el notario Almúnia fue anotando los hechos más relevantes de la ciudad desde 1265 hasta 1620, utilizando como principal fuente de documentación las actas municipales que se conservaban en el archivo de la ciudad. En una serie de referencias sobre la familia Villafranca en el siglo XV en el manuscrito, el apellido aparece de forma intencionada, tachado o mal escrito. En anotación al margen leemos: «En el borrado de este y todo los demás, dezía Villafranca, y por figurarse cavalleros antiguos, no quieren que beran que eran ciudadanos, lo que debían tener a mucha onra. Y si estos libros no se sacaran del archivo, nadie tendría atrebimiento de borrar nada». La obra ha sido publicada en fechas recientes. MAS I MiRAlles. A., Antoni Almúnia: Libre de tots los actes, letres, privilegis y altres qualsevol provisions del Consell d'Oriola, Valencia, Universitat de València, 2008, pág. 175. El texto refleja de forma elocuente el giro histórico de la familia Villafranca. En el siglo XV la ciudadanía supondría una gran honra para dicha familia. En el siglo XVII el pasado ciudadano de los antepasados del linaje era un estigma que había que borrar de la Historia a toda costa.

${ }^{93} \mathrm{Al}$ analizar el impacto de la propaganda política es interesante conocer la incidencia en los potenciales destinatarios. En el periodo que acaba en los años setenta del siglo XIX el impacto de 
los castellanos en la guerra de los dos Pedros, hasta la forja de una gran urbe, que se había elevado al rango de ciudad en $1437^{94}$ y que aspiraba a disponer de un obispado propio, que enviaba a sus embajadores a los principales centros de poder, incluido el Papado, mostrando el orgullo de la república.

Aninadvertentes grandia illa pergrataque servicia que fidelis villa nostra Oriole dicti Regni Valentie nobis serenissimisque predecessoribus nostris diversimode diversisque temporibus florentis scilicet pacis et bellorum presertim in serenissimos reges Castgelle gestorum sponte sua ac magna cum integrate prestitis, prestat ad presents et prestatura sperantes dante domino meliora, sedulaque meditatione pensantes, quod omnia illa tria in se continent, ex quibus nulla quesita ope ipsa sibi sufficit ad bene vivendum et ex quibus civitas constat, puta agrícolas, artífices, propulsatores belli, quos alii melites a malo arcendo, quia propulsando bellum, civibus malum arcent; alii vero custodes appellaverunt, quod idem esse videtur, cum qui malum arcet a civibus, nihil aliud faciat quam civitatem custodire et qui rem publicam custodit nil aliud hagat quam malum arcere a civibus...

Pro premissis igitur respectibus digne moti et aliter ad humiles supplicationes suas, pro parte sua per Eximenum Petri, decretorum licenciatum et Jacobum de Podio prepositum et Vicarium generalem et Guillermum de Vico, oratores suos...

Et quonian regnum nostrum nomen ac signum felix et faustum domus nostre Aragonum prout fidelis decet summa cum integrate atque constantia in corde atque visceribus impressum semper gessit in ampliorem ipsius laudem et decorationem per nos heredes et successores nostros quoscunque, promittimus quod dominum nostrum vel Sacrum Basiliense Concilium aut aliut eficacem operam dabimus ut in dicta civitate Oriole Sedes et Ecclesia Cathedralis ordinetur cui pressit, qui episcopatum habeat limitibus et redditibus prout episcopal congruhit dignitati limittatum dotatumque ${ }^{95}$.

En esta historia reconstruida, los momentos decisivos para sus cúpulas dirigentes corresponden a los grandes episodios bélicos de la ciudad. La conquista cristiana del territorio a los musulmanes y la forja de un nuevo espacio. La amenaza latente, real o exagerada, de ataques procedentes desde al-Andalus a las tierras valencianas permitía retroalimentar la llamada «neurosis» granadina y con ello realzar el valor histórico de los conquistadores y de sus legítimos descendientes y sucesores. Este pasado combativo contra «la fétida nación musulmana» 96 fue utilizado por las elites dirigentes para justificar el origen hono-

las coronaciones reales en Gran Bretaña era mínimo. CANNADINE, D., «Contexto, representación y significado del ritual: la monarquía británica y la "invención de la tradición"», en HOBSBAWN, E. y RANGER, T., (eds.), La invención de la tradición, Barcelona, Crítica, 2002, págs. 116-118. La iconografía propagandística de Orihuela estaban en su mayor parte ubicada en el interior de los templos cristianos, por lo que no estaba proyectada ni dirigida para destinatarios judíos o musulmanes.

${ }^{94}$ Estal, J.M., Oribuela. De Villa a Ciudad, Alicante, Ayuntamiento de Orihuela, 1996.

${ }^{95}$ Estal, J.M., Oribuela. De Villa a Ciudad, págs. 118-121 (1437, septiembre, 11).

96 Jaime II autorizó la formación de una cofradía que tenía por objetivo la «destruccionem sarracenorum fetide naciones». ACA, Reg. 322, fol. 1r. (1315, septiembre, 20). Creemos que está 
rable de su linaje, los servicios prestados a la cristiandad y a la Corona, y la justificación y la necesidad del gobierno que ejercían

a honor... de la Sancta Trinitat e de la Verge gloriosa nostra dona sancta Maria e de tota la cort celestial e a impugnaçio e destruiment de la malvada secta de Mahomet a suplicacio dels prohomens de la ciutat de Barcelona es ordenada la confraria deius escrita ${ }^{97}$.

Otro gran hito recogido en la memoria histórica de las urbes del sur del reino de Valencia fue la guerra con Castilla. Todos los enfrentamientos bélicos suscitados en torno a la frontera con Castilla fueron utilizados como argumento recurrente de orgullo y de lealtad y fidelidad renovada a la monarquía. Dos episodios destacan, la guerra de los dos Pedros durante el reinado de Pedro IV el Ceremonioso y la guerra de Castilla en 1429 durante el reinado de Alfonso V el Magnánimo.

Las ciudades del reino de Valencia, al construir su propia memoria ${ }^{98}$ histórica con una fuerte impronta providencial, no dudaban en arrumbar, eliminar o destruir la historia de otros centros urbanos, practicando la damnatio memoriae más despiadada. Así sucedió tras la guerra de los dos Pedros, momento decisivo en la construcción de la identidad y la memoria histórica del reino de Valencia. Villas con su propia historia e identidad como Guardamar, Murvedre o Monforte perdían su condición de Universitas, su condición de municipio, su autonomía y eran desposeídas de su título de villa para convertirse en calles de otros municipios, Orihuela, Valencia y Alicante respectivamente. La villa de Guardamar no recuperó su autonomía municipal hasta 1692. En los privilegios concedidos por Pedro IV a la villa de Orihuela tras la guerra de los dos Pedros, además de la incorporación de Guardamar al término municipal oriolano, confirmaba los primitivos privilegios de Alfonso $\mathrm{X}$ en los que Orihuela recibía su alfoz o término municipal. En estos primeros privilegios aparecía el topónimo Almodovar como uno de los lugares del alfoz oriolano. En el privilegio concedido por Pedro IV a la villa de Orihuela, por el que confirmaba el término del municipio, Almodovar se transmutaba en Guardamar — «Almudavar qui nunc dicitur Guardamar»—, por la mano y gracia del escribano redactor del privilegio y de un plumazo se borraba la Historia de Guardamar ${ }^{99}$, que de esta forma quedaba incorporada al origen fundacional de

inspirada en los conceptos de identidad de una comunidad cristiana en el seno de la Corona de Aragón y planteados por Arnau de Vilanova, que defendió una clara acción militar contra los musulmanes a través de una "confratria ordinata per armata faciendi contra perfidos Sarracenos». Santi, F. Arnau de Vilanova. L'obra espiritual, Valencia, Diputación Provincial de Valencia, 1987, págs. 232-233.

${ }^{97}$ ACA, Reg. 322, fol. 1r. (1315, septiembre, 20).

${ }^{98} \mathrm{La}$ identidad, en este caso, forma parte del discurso de la memoria. KLEIN, Kerwin Lee, «On the Emergence of Memory in Historical Discourse», Representations, California, University of California Press, 69 (2000), pág. 143.

${ }^{99}$ En este caso el papel de la escritura sirve de forma eficaz como dispositivo mnemónico, como ayuda para la memoria. Olson, El mundo sobre el papel, pág. 16. 
la villa de Orihuela como una de sus aldeas ${ }^{100}$. Toda posible historia medieval propia de los guardamarencos desapareció de la memoria histórica, al no haber conservado Guardamar su documentación de época medieval y, sobre todo, al perder su independencia municipal a manos de la villa de Orihuela, que se apropió de su historia y la agregó al acervo histórico de los orígenes de la capital de la Gobernación de Orihuela y de su gloriosa historia fundacional ${ }^{101}$.

La donación que hacía Pedro IV a la villa de Orihuela del lugar de Guardamar se justificaba como gratificación o recompensa por los extraordinarios servicios prestados por la Universitas y los hombres probos en la defensa que hicieron de la villa ante el ataque que sufrieron por las tropas castellanas en la guerra de los dos Pedros. Guardamar, por contra, perdía su autonomía municipal por una supuesta traición, al rendir la villa sin oponer resistencia a las tropas castellanas. Esta era la versión oficial de la reconstrucción de la memoria histórica de Orihuela, ratificada años después por el cronista Bellot que en sus Anales de Orihuela se hacía eco de esta versión, mientras que Zurita había defendido un largo asedio sobre las débiles defensas de la villa de Guardamar ${ }^{102}$. Una ciudad, por tanto, Orihuela, que al construir su propia memoria histórica necesita destruir la de otra villa, Guardamar, y reforzaba con ello su papel de capitalidad y su hegemonía sobre el territorio de la Gobernación de Orihuela.

De los tres registros temporales de la memoria histórica, la más decisiva, la perpetua, la imperecedera, se construía sobre la memoria fósil e intangible de las costumbres, las leyendas y los privilegios y libertades de la ciudad ${ }^{103}$, recogidos en los textos sacros de la urbe, los libros de privilegios y otros códices, que, tratados como auténticos tesoros, eran custodiados con celo en el archivo municipal.

\section{CONCLUSIONES}

El desarrollo de un elaborado discurso político y una potente identidad urbana en una villa de tamaño medio con una fuerte impronta rural es un hecho que debe ser considerado por la historiografía. Frente al papel desempeñado por la realeza, el imperio o el papado, en la forja de modelos discursivos e identidades específicas, reivindicamos el papel protagonista de los centros urbanos.

${ }^{100}$ AMO, Códice becerro. Libro de privilegios, ff. 61v-63r. (1365, septiembre, 24).

${ }^{101}$ En realidad y como he demostrado, Guardamar fue una villa fundada por Alfonso X en torno a 1271, que la dotó con el Fuero de Alicante y que fue incorporada como Universitas a la Corona de Aragón por Jaime II en 1296, llegando a tener representación en las Cortes del reino, celebradas en Valencia entre 1329 y 1330. BARRIO BARRIO, J.A., «La villa de Guardamar. 1271-1329», Alquibla, 6 (2000), págs. 375-401.

102 Cabezuelo Pliego J.V., La Guerra de los dos Pedros en las tierras alicantinas, Alicante, Instituto de Cultura Juan Gil-Albert, 1991.

${ }^{103}$ Grava, «La mémoire, une base de 1'organisation politique», págs. 79-80. 
El estudio de ambos paradigmas, discurso político e identidad urbana, requiere de nuevos enfoques. En este estudio hemos presentado como elementos prioritarios de análisis la posición geo-histórica de un territorio, en este caso, su ubicación periférica y fronteriza, su posición de capitalidad territorial y el conflicto eclesiástico-episcopal, amén del papel desempeñado por las confrontaciones bélicas en una zona en litigio entre dos grandes potencias europeas, que nos muestran la necesidad de escudriñar y estudiar determinados espacios históricos, tanto en su singularidad y especificidad como en su correcta contextualización, con los fenómenos globales desarrollados en la cristiandad occidental.

Recibido: 25-06-2010.

Aceptado: 29-10-2010. 